\title{
The Cooperation of Japan-Indonesia in the Oil Palm Sector
}

\author{
Ngadi \\ Research Center for Population \\ Indonesian Institute of Sciences \\ Jakarta, Indonesia
}

\author{
Triyono \\ Research Center for Population \\ Indonesian Institute of Sciences \\ Jakarta, Indonesia
}

\begin{abstract}
Indonesia and Japan have established cooperation in various fields including investment and exportimport of oil palm sector. Although Indonesia has the largest palm oil production in the world, palm oil exports from Indonesia to Japan are lower than Malaysia. This research aims to explore the cooperation of Japan-Indonesia in the oil palm sector mainly in export-import and investment. Research uses quantitative and qualitative approach. Quantitative data were collected from various agencies in Indonesia while qualitative data conducted with in-depth interviews on various stakeholders. The result of the study shows that in 2018 Indonesia is the second largest supplier of oil palm in Japan with 40.0 percent share while Malaysia is the largest supplier with a 59.1\% share. The export value of Indonesian oil palm products to Japan in 2018 is US\$ 217.7 million. The trend of oil palm export in the last five years reached $30.24 \%$. Indonesia has big opportunity to increase oil palm exports to Japan because Indonesia is the largest oil palm producer in the world. On the other hand, the demand of vegetable oil in Japan continues to increase both for renewable energy sources, cosmetic industry and cooking oil. Palm oil also has greater productivity compared to other vegetable plants. The development of oil palm exports has some challenges, especially market competition, product quality, export procedures, and negative campaign of oil palm plantation. With the negative campaign, the palm oil market is hampered because many Japanese companies require RSPO certification.
\end{abstract}

\section{Keywords-cooperation, palm oil, investment}

\section{INTRODUCTION}

Japan is one of the strategic partners in Indonesia's foreign relations for trade, investment and research. In trade, Japan is the third largest destination country for non-oil and gas exports from Indonesia after China and the United States. In 2017 the value of non-oil exports from Indonesia to Japan reached 14,690.6 million US dollars), up from 9,934.4 million US dollars in 2016 (Kemendag.go.id). In the field of investment Japan is the country with the second largest investment value after Singapore. In 2016 the value of Japanese investment in Indonesia reached 5.4 M US \$ or $18.6 \%$ of all foreign investment in Indonesia. In research and development activities, Japan has done a lot of cooperation with Indonesia such as educational scholarships, research cooperation with domestic institutions in Indonesia.

One of the leading competitions in Indonesia developed in Japan's Indonesian cooperation is the oil palm plantation sector. Indonesia is the largest producer of palm oil in the world, but in 2018 Indonesia only accounts for $40.6 \%$ of the demand for palm oil in Japan. Most of the country's palm oil is supplied by Malaysia, which accounts for $59.1 \%$. Indonesia's role has indeed increased compared to 1987 where Indonesia supplied $3.6 \%$ of palm oil in Japan, while Malaysia supplied $96.3 \%$. However, it is still small if it is connected with Indonesia's place as the world's largest palm oil producer. In the field of investment, few Japanese companies invest in the palm oil sector in Indonesia. This research will answer the question why Japanese investment and exports in Indonesia are still small, even though Indonesia is the largest producer of palm oil in the world? Research uses quantitative and qualitative approach. Quantitative data were collected from various agencies in Indonesia while qualitative data conducted with in-depth interviews on various stakeholders.

\section{JAPAN-INDONESIA COOPERATION IN THE OIL PALM SECTOR}

Indonesia is one of the countries included in the G20 and carries out various cooperate agreements in the economic field with other countries. One of the countries that formed the partnership was Japan, which became one of the main destinations for Indonesia's exports. To further strengthen cooperation, Indonesia and Japan entered into an agreement with the IJEPA-Indonesia Economic Partnership Agreement scheme.

The close economic relations between Indonesia and Japan can be seen in 2017 trade data, where Japan is the second export destination for Indonesia and Japan, which is the third import source for Indonesia. The value of Indonesia-Japan trade transactions in 2017 reached USD 33.03 billion with export details of 17.79 billion, imports of USD 15.24 billion and a surplus of USD. 2.55 billion (Ministry of Trade, 2018). The main exports to Japan are coal products, iron ore, precious metal scraps, rubber and insulated wire.

Seeing the export data that is still dominated by the mining, it is necessary to encourage other commodities such as oil palm. Furthermore, IJEPA spoke not only related to exports and imports but also other problems such as investment, labor and intellectual property. Therefore, the collaboration in the IJEPA scheme is very broad and can be used to increase the opportunities to attract large amounts of investment, such as invest oil palm plantations.

\section{OPPORTUNITIES FOR PALM OIL EXPORTS TO JAPAN}

The opportunity to export palm oil products and their derivatives to Japan is very large. Palm oil can be used as an ingredient to meet the needs of the industrial industry, oil and the need for energy. Energy needs, especially palm 
kernel shells as one of its derivative products are used to replace the role of nuclear energy as a source of electricity. At present, the export capacity of palm kernel shells is about 500,000 tons. This need is expected to increase considering that Japan will cut its dependence on nuclear energy to supply electricity and rank environmentally friendly energy. This is not separated from the leak of the Fukushima nuclear reactor which requires the Japanese State to divert other energy supplies, especially non-fossils. The energy crisis that occurred in Japan led to the import of coal from Indonesia because the Japanese government encouraged the use of natural energy.

Japanese government does not prohibit the import of oil palm from Indonesia, but there are fears that small farmers in Indonesia cannot sell oil palm because they do not have RSPO certificates. According to tell one of the universities in Japan that only large farmers can get RSPO certificates. In addition, another challenge that arises is that palm oil froze quickly. This is as stated by one of the informants from the trade ministry who stated that palm oil is rapidly freezing. Oil palm must also compete with other vegetable oil products because before 2000 Japan had used soybean oil.

TABLE I. LIST OF SUPPLYING MARKETS FOR A PRODUCT IMPORTED BY JAPAN

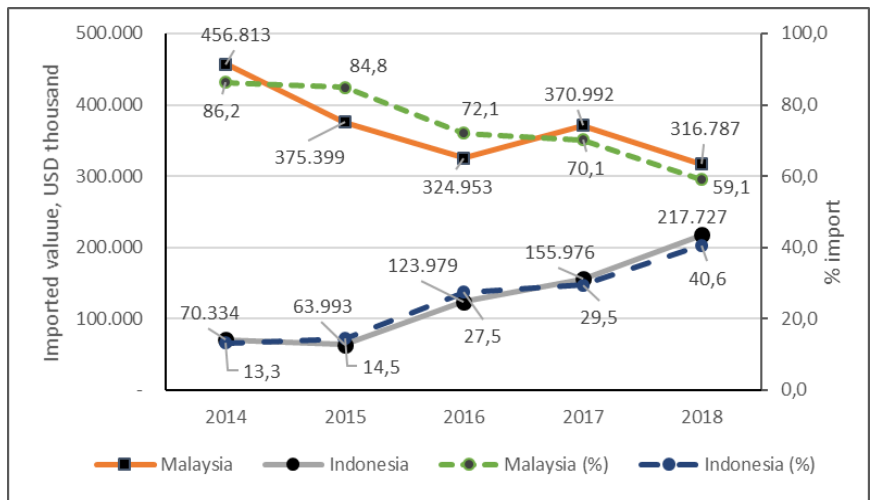

Product: 1511 Palm oil and its fractions, whether or not refined (excluding chemically modified) Source: International Trade Center

Based on data from the Indonesian Ministry of Trade, there is an increase in the value of Indonesia's palm oil exports to Japan from 45 million US dollars to 203 million USD in 2018. Most of the exports are Refined Bleached Deodorized (RBD) products. In terms of the proportion of palm oil supply in Japan, Indonesia also experienced an increase from $6.3 \%$ in 2011 to $27.5 \%$ in 2016.

\section{A. Barriers to Exporting Palm Oil to Japan}

Exports become one of the sources of state foreign exchange revenues that need to be improved both in terms of quality and measure. One that is being upgraded is nonoil exports, namely oil palm. Palm oil is a mainstay in bringing in foreign exchange, so it is not surprising that oil palm is one of the main sources in the Indonesian economy (Rifin Amzul, 2010: 173). Aside from being an export commodity, oil palm becomes a material in Indonesian cuisine (Soetrisno and Winahnyu 1991 in Rifin Amzul, 2010: 173). Therefore, oil palm moves the real sector such as street vendors, to restaurants because of using palm oil products. Amzul Rifin (2010: 173) further explained that oil palm is a sector that absorbs large numbers of workers. Therefore, oil palm is one of the backbones of the Indonesian economy. Therefore, many dubs palm oil as a grain of black gold. However, oil palm experiences major challenges ranging from environmental issues to human rights.

The developing image affects companies that will invest in the oil palm plantation sector. Because there is an image of Japanese society that companies that invest in the oil palm plantation sector are considered to support forest destruction. The professor further said that "Even though in reality oil palm plantations have promoted the economy such as in Sumatra and Kalimantan". Therefore, palm oil, plantations does not marginalize the poor even improve the regional economy. Based on satellite imagery (Gunarso et al., 2012 in Purba and Sipayung 2017: 81) showing transforms primary forest to oil palm plantations is only 3.4 percent of the overall origin of Indonesian plantation land. Because deforestation that develops overseas supported by a black palm oil campaign needs to be straightened out. This black campaign will ultimately make the world more difficult to accept oil palm as an environmentally friendly export product.

Although in practice there are management of oil palm plantations that are not environmentally friendly, they are only small scale and most of them have carried out plantations in accordance with the corridors that comply with the rule of law and the environment. This is also expressed by Purba and Sipayung (2017: 82) the issue of deforestation is used to suppress the growth of Indonesia's oil palm plantations even though the Indonesian government already has ISPO standards. On the other hand problems due to palm oil opening need to be resolved quickly and on target. Quoting state Oliver Pye and Jayati Bhattacharya in review Tim Forsyth (2013: 555,) "rapid growth of various conditions and key indicators of species such as change from biofuel through fires, deforestation, and conflicts to land claims, labor conditions, and human rights abuses". These problems are still a major problem to date to find a solution. Because after all the negative campaign by other countries even NGOs themselves are no longer healthy just based on the problems that occur due to the opening of oil palm land and have led to trade competition.

At the international level, the policy that guides trade is RSPO and has not recognized ISPO. Japan is also still oriented to Europe which applies the RSPO standard as one of the conditions for the entry of oil palm into their trade. Thus, when Europe boycotted Indonesian palm oil products for environmental reasons it would affect the market in Japan. Even though what actually happened was a trade war because cheap palm oil would rival solar oil and soybeans produced by Europe. Oil palm will kill the soybean and solar oil industry from Europe. This European boycott is one way to protect farmers and parties involved sun and soybean industries. The advantages of oil palm are having a high economic value but Indonesia has an ISPO that has not been recognized internationally. According to a key informant from Japan that the key word in oil palm cooperation with Japan is RSPO because the RSPO is an international standard. Quoting from the statement Adrienne Johnson (2014: 184) "certification standard of rectifying the major 
power industry in the forging positive and green social, economic, and environmental pathways for the energy sector". Efforts to promote ISPO certificates need to be carried out so that this certificate can be recognized and accepted by other countries including Japan.

On the other hand, NGOs in Japan are very active in giving attention to the oil palm plantation industry. Japan also does not know about the ISPO used by Indonesia, although most ISPO indicators are almost the same as those in the RSPO. Looking at these problems, what needs to be done is to recognize that there is still something that needs to be improved from oil palm plantations in Indonesia. Franz et al. (2013: 132) state important measures of limitations, which in no way can close ecological truths. In addition, it guarantees the rights of local people. On the other hand, concern in oil palm plantation companies that pay attention to the environment will support welfare (Djajadiningrat, 2011: 55).

In the field of investment, Japanese companies are more interested in their core investments such as in the field of transportation, automotive. This is as stated by one of the informants from the Investment Coordinating Board (BKPM). Therefore, investment in the oil palm plantation sector is very small even recorded in 2017 only 1 company. Therefore, a much effort from related ministries is needed to maximize investment from Japan so that it will increase in the plantation sector, especially oil palm. The investment meant is not only in plantation management, but also in the downstream industry even after the downstream is in the form of palm shells which are actually used as environmentally friendly energy.

\section{B. The Role of Government in the Oil Palm Export}

Until now the government has made various efforts to support exports. One of them is by strengthening cooperation and promotion both to the main oil palm destination countries and other countries such as Japan. This is as expressed by the Ministry of Trade. That the effort that has been made is by strengthening promote oil palm. On the other hand, attached that are abroad also carry out various promotional efforts to make Indonesian palm oil accepted by the global market. Besides that, it is necessary to strengthen the international lobby on oil palm which is propoor and pro-growth as well as pro-ecology.

\section{CONCLUSION}

Palm oil is one product that plays an important role in the Indonesian economy. Therefore, the policy for cooperation to increase palm oil exports needs to be intensively carried out with various countries. Japan is one of the potential countries to receive palm oil products. With the black campaign from the European Union which has affected the oil trade balance, it is necessary to open new markets. On the other hand, Japan desperately need palm oil derivative products, especially palm oil cake as one of the alternative energy sources for electricity in Japan.

But to increase the palm oil market to Japan, Indonesia faces various challenges such as market competition with
Malaysia which has dominated the Japanese market for a long time and has complicated export rules. For this reason, policy measures are needed such as strengthening and accelerating business licensing and legal certainty. In addition, for quality oil palm must be maintained in addition to the need to fight against negative palm oil campaigns. expands market share is needed to make sure that palm oil products are one of the mainstays of non-oil and gas sector foreign exchange earnings.

\section{REFERENCES}

[1] Department of Plantation (2016). Statistik Kelapa Sawit tahun 2015. Departemen Perkebunan, Kementerian Pertanian Indonesia.

[2] Jan Horas V. Purba, Tungkot Sipayung. (2017). Perkebunan Kelapa Sawit Indonesia Dalam Perspektif Pembangunan Berkelanjutan*. Masyarakat Indonesia, $\begin{array}{llll}\text { Vol. } & 43 & \text { No.1, } & \text { Juni }\end{array}$ http://jmi.ipsk.lipi.go.id/index.php/jmiipsk/article/view/717/521.

[3] Johnson, Adrienne. 2014. Ecuador's National Interpretation of the Roundtable on Sustainable Palm Oil (RSPO): GreenGrabbing through Green Certification?. Journal of Latin American Geography, Vol. 13, No. 3 (2014), pp. 183-204 Published by: University of Texas Press; Stable URL: https://www.jstor.org/stable/24395772 Accessed: 04-01-2019 02:24 UTC.

[4] Kementerian Perdagangan. 2018. Factsheet Indonesia-Japan Economic Partnership Agreement (IJEPA). http://ditjenppi.kemendag.go.id/assets/files/publikasi/doc_20180515 _fact-sheet-indonesia-japan-economic-partnership-agreementijepa1.pdf. Diunduh 3 Januari 2019

[5] Peter Franz, Florian Mayer Dan Stefan Tidow. 2013. Kebijakan Industri Ekologis: Kebijakan Pertumbuhan Berkelanjutan, Dalam Simon Vaut dkk, buku Bacaan Sosial Demokrasi 2 Ekonomi Dan Sosial Demokrasi Diterjemahkan Oleh Ivan H Haidar. Jakarta: Friedrich Ebert-Stiftung Kantor Perwakilan Jakarta.

[6] Rifin, Amzul. 2010. The Effect of Export Tax on Indonesia's Crude Palm Oil (CPO) Export Competitiveness. ASEAN Economic Bulletin, Vol. 27, No. 2 (August 2010), pp. 173-184: ISEAS - Yusof Ishak Institute Stable URL: https://www.jstor.org/stable/41317117 Accessed: 04-01-2019 02:23 UTC

[7] Surna Tjahja Djajadiningrat, Yeni Hendriani, Melia Famiola. 2011. Ekonomi Hijau/Green Economy. Bandung : Rekayasa Sains

[8] Tim Forsyth. 2013. Reviewed Work (s): The Palm Oil Controversy in Southeast Asia: A Transnational Perspective by Oliver Pye and Jayati Bhattacharya Review. Source: Bijdragen tot de Taal-, Land- en Volkenkunde, Vol. 169, No. 4 (2013), pp. 555-557. Brill Stable URL: https://www.jstor.org/stable/43817916 Accessed: 04-01-2019 02:25 UTC.

[9] Susilowati, S.H., and A. Suryana (1988). Situasi Pasar Minyak Sawit di Jepang, Jurnal Agro Ekonomi, Vol 7, No 2 (1988), Pusat Sosial Ekonomi dan Kebijakan Pertanian, Kementerian Pertanian

[10] Bambang Dradjat and Prajogo U. Hadi. (1996). Daya Saing Minyak Kelapa Sawit Indonesia Di Pasar Eropa Barat, Amerika Serikat, dan Jepang; Jurnal Agro Ekonomi Vol 15, No 1 (1996); Pusat Sosial Ekonomi dan Kebijakan Pertanian, Kementerian Pertanian

[11] ITPC Osaka. 2012. Market Brief HS 1511 Minyak Kelapa Sawit, ITPC Osaka, Japan

[12] http://www.kemendag.go.id/id/economic-profile/10-main-andpotential-commodities

[13] http://www.kemendag.go.id/id/economic-profile/10-main-andpotential-commodities

[14] https://sipuu.setkab.go.id/PUUdoc/175597/INPRES\%208\%20TAHU N\%202018.PDF 